\title{
Bioremediation of Chromium Contaminated and Harbor Dredged Soil
}

\author{
K.Jimreeves Donald, P.D.Arumairaj, Jeya Priya.J
}

\begin{abstract}
Soil contamination is caused by the presence of manmade chemicals in the natural soil environment. It is often caused by some form of industrial activity, agricultural chemicals or the improper disposal of waste. The most common chemicals involved in soil pollution are petroleum hydrocarbons, pesticides and lead and other heavy metals. Heavy metals are among the major environmental pollutants and the accumulation of these metals is a great concern in agricultural production due to the toxic effects it has on crop growth. Remediation of soil is a challenging process but if done perfectly it can yield very good results. Firstly the physical and chemical properties of the soil are tested for understanding the properties of the soil. Test such as sieve analysis, liquid and plastic limit are done to understand the characteristics of the soil. The contaminants and their concentration in the soil can be identified using SEM ANALYSIS and EDAX. The soil is remediated using purpose which suits the nature of the soil. Remediation of soil can be done using either micro organism, chemicals, plants, by passing high voltage current or by other physical purposes. Use of micro organisms is one of the advanced methods of remediation. Micro organisms such as pseudomonas aeruginosa, pseudomonas alcaligenes, and pseudomonas hibisciola are used for remediating the heavy metals of the soil. The micro organisms are inoculated in the contaminated soil and tests such as $\mathrm{pH}$, temperature, $U V$ spectroscopy $620 \mathrm{~nm}$ are conducted to understand the effect of micro organisms on the soil. Atomic Absorption Spectroscopy is finally conducted for the Oth hour and 100th hour to understand the amount of heavy metal reduction in the soil samples.

Keywords:-soil properties, engineering properties, chromium contaminated, harbor dredged, remediation.
\end{abstract}

\section{INTRODUCTION}

The process of removal of pollution or contaminants from environmental media such as soil, groundwater, sediment, or surface water is called remediation. Soil which is wealthy and free from any form of contamination gives growth to clean and natural trees and vegetation, as well as contributing to healthy air and groundwater. If there are heavy metals contents present in the soil then they can cause serious defects to life and also plants and properties. When the chromium content present in the soil gets in the food chain it can cause serious effects to life of both animals and humans. This can lead to serious deterioration to human life. Thus, it is very much important to remediate the heavy metal content present in the soil. Contaminated soil samples are obtained from the following two locations.

1. Chromium Contaminated Soil, Ranipet.

Revised Manuscript Received on April 12, 2019.

K.Jimreeves Donald, P.D.M.Tech Scholar, Environmental Engineering, Karunya Institute of Technology and SciencesCoimbatore, Tamil Nadu, India.

Arumairaj,Professor \& Head, Department of Civil Engineering, Karunya Institute of Technology and SciencesCoimbatore, Tamil Nadu, India.

JeyaPriya.J, Assistant Professor, Department of Civil Engineering, Karunya Institute of Technology and SciencesCoimbatore, Tamil Nadu, India.
2. Dredged Harbor Sea Soil, Thoothukudi

\section{METHODOLOGY}

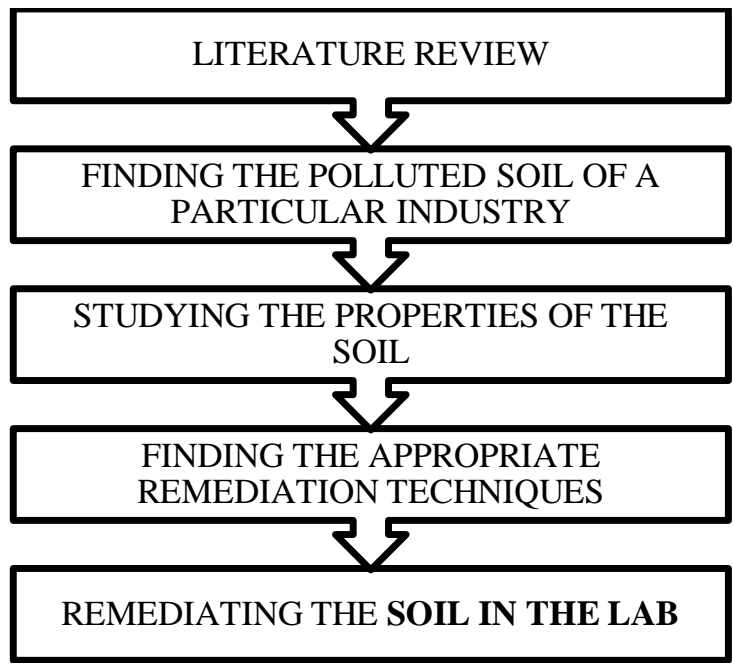

III. RESULTS \& DISCUSSION

1. Specific gravity test

2. Sieve analysis test

3. Liquid Limit Test

4. Plastic Limit Test

5. Direct Shear Test

SPECIFIC GRAVITY RESULTS

\begin{tabular}{|l|l|}
\hline Chromium contaminated & $\mathrm{G}=2.618$ \\
\hline Dredged sea soil & $\mathrm{G}=2.608$ \\
\hline
\end{tabular}

SIEVE ANALYSIS OF DREDGED SEA SOIL

\begin{tabular}{|c|c|c|c|c|}
\hline Sieve & $\begin{array}{c}\text { Retained } \\
\text { wt }\end{array}$ & $\begin{array}{c}\text { Retained } \\
\mathbf{\%}\end{array}$ & $\begin{array}{c}\text { Cumulative } \\
\mathbf{\%}\end{array}$ & $\begin{array}{c}\text { Pass } \\
\mathbf{\%}\end{array}$ \\
\hline 4.75 & 157 & 15.7 & 15.7 & 84.3 \\
\hline 3.35 & 60 & 6 & 21.7 & 78.3 \\
\hline 2.36 & 135 & 13.5 & 35.2 & 64.8 \\
\hline 1.18 & 133 & 13.3 & 48.5 & 51.5 \\
\hline 0.600 & 98 & 9.8 & 58.3 & 41.7 \\
\hline 0.450 & 154 & 15.4 & 73.7 & 26.3 \\
\hline 0.15 & 198 & 19.8 & 93.5 & 6.5 \\
\hline 0.075 & 37 & 3.7 & 97.2 & 2.8 \\
\hline Pan & 26 & 2.6 & 99.8 & 0.2 \\
\hline
\end{tabular}

$$
\begin{array}{ll}
\checkmark & \mathrm{C}_{\mathrm{u}}=11.76 \\
\checkmark & \mathrm{C}_{\mathrm{c}}=4.47 \\
\checkmark & \mathrm{D}_{10}=0.17
\end{array}
$$


$\checkmark$ Coarse Sand $=15.7 \%$

$\checkmark$ Medium Sand $=42.6 \%$

$\checkmark$ Fine Sand $=38.9 \%$

$\checkmark$ Silt \& Clay $=2.6 \%$

\section{SIEVE ANALYSIS OF CHROMIUM CONTAMINATED SOIL}

\begin{tabular}{|c|c|c|c|c|}
\hline Sieve & $\begin{array}{c}\text { Retained } \\
\mathrm{Wt}\end{array}$ & $\begin{array}{c}\text { Retained } \\
\%\end{array}$ & $\begin{array}{c}\text { Cumulative } \\
\%\end{array}$ & $\begin{array}{c}\text { Pass } \\
\%\end{array}$ \\
\hline 4.75 & 20 & 2 & 2 & 98 \\
\hline 3.35 & 29 & 2.9 & 4.9 & 95.1 \\
\hline 2.36 & 69 & 6.9 & 11.8 & 88.2 \\
\hline 1.18 & 163 & 16.3 & 28.1 & 71.9 \\
\hline 0.600 & 175 & 17.5 & 45.6 & 54.4 \\
\hline 0.450 & 234 & 23.4 & 69 & 31 \\
\hline 0.150 & 179 & 17.9 & 86.9 & 13.1 \\
\hline 0.075 & 104 & 10.4 & 97.3 & 2.7 \\
\hline Pan & 25 & 2.5 & 99.8 & 0.2 \\
\hline
\end{tabular}

$$
\begin{array}{ll}
\checkmark & \mathrm{Cu}=6.41 \\
\checkmark & \mathrm{Cc}=1.56 \\
\checkmark & \mathrm{D} 10=0.12 \\
\checkmark & \text { Coarse Sand }=2 \% \\
\checkmark & \text { Medium Sand }=43.6 \% \\
\checkmark & \text { Fine Sand }=51.7 \% \\
\checkmark & \text { Silt \& Clay }=2.5 \%
\end{array}
$$

\section{LIQUID LIMIT TEST}

The Liquid Limit of both the Chromium Contaminated Soil and Dredged Sea Soil could not be determined because of the low clay content present in the soil.

\section{PLASTIC LIMIT TEST}

The Plastic Limit of both the Chromium Contaminated Soil and Dredged Sea Soil could not be determined because of the low clay content present in the soil.

\section{DIRECT SHEAR TEST}

The direct shear test is taken for the chromium contaminated soil sample for three different loads.

Load $=0.1 \mathrm{~kg} / \mathrm{cm}^{3}$

\begin{tabular}{|c|c|c|c|}
\hline $\begin{array}{c}\text { Displacement } \\
\text { Dial } \\
\text { Readings }\end{array}$ & $\begin{array}{c}\text { Proving } \\
\text { Ring } \\
\text { Readings }\end{array}$ & Load in N & $\begin{array}{c}\text { Shear } \\
\text { Stress x 10-2 } \\
\mathbf{N} / \mathbf{m m}^{\mathbf{2}}\end{array}$ \\
\hline 50 & 17 & 22.24 & 0.6178 \\
\hline 100 & 30 & 39.6 & 1.1 \\
\hline 150 & 37 & 48.84 & 1.3567 \\
\hline 200 & 48 & 63.36 & 1.76 \\
\hline 250 & 53 & 69.96 & 1.943 \\
\hline 300 & 58 & 76.56 & 2.1267 \\
\hline 350 & 59 & 77.88 & 2.163 \\
\hline 400 & 59 & 77.88 & \\
\hline
\end{tabular}

$\operatorname{Load}=0.2 \mathrm{~kg} / \mathrm{cm}^{3}$

\begin{tabular}{|c|c|c|c|}
\hline $\begin{array}{c}\text { Displacement } \\
\text { Dial Readings }\end{array}$ & $\begin{array}{c}\text { Proving } \\
\text { Ring } \\
\text { Readings }\end{array}$ & Load in N & $\begin{array}{c}\text { Shear Stress } \\
\times 10^{-2} \\
\mathrm{~N} / \mathrm{mm}^{2}\end{array}$ \\
\hline 50 & 53 & 69.96 & 1.943 \\
\hline
\end{tabular}

\begin{tabular}{|l|l|l|l|}
\hline 100 & 59 & 77.88 & 2.163 \\
\hline 150 & 62 & 81.84 & 2.273 \\
\hline 200 & 63 & 81.84 & 2.273 \\
\hline
\end{tabular}

Load $=0.3 \mathrm{~kg} / \mathrm{cm}^{3}$

\begin{tabular}{|c|c|c|c|}
\hline $\begin{array}{c}\text { Displacement } \\
\text { Dial } \\
\text { Readings }\end{array}$ & $\begin{array}{c}\text { Proving } \\
\text { Ring } \\
\text { Readings }\end{array}$ & Load in N & $\begin{array}{c}\text { Shear } \\
\text { Stress } \\
\mathbf{x ~ 1 0} \\
\mathbf{N} \mathbf{m m}^{\mathbf{2}}\end{array}$ \\
\hline 50 & 48 & 63.36 & 1.76 \\
\hline 100 & 62 & 81.84 & 2.259 \\
\hline 150 & 70 & 92.4 & 2.567 \\
\hline 200 & 74 & 97.68 & 2.713 \\
\hline 250 & 74 & 97.68 & 2.713 \\
\hline
\end{tabular}

\begin{tabular}{|c|c|c|}
\hline Parameters & $\begin{array}{c}\text { Chromium } \\
\text { contaminated }\end{array}$ & Dredged sea soil \\
\hline Chloride & $251.27 \mathrm{mg} / \mathrm{l}$ & $5.0055 \mathrm{mg} / \mathrm{l}$ \\
\hline Total hardness & $150 \mathrm{mg} / \mathrm{l}$ & $92 \mathrm{mg} / \mathrm{l}$ \\
\hline $\begin{array}{l}\text { Calcium } \\
\text { hardness }\end{array}$ & $70 \mathrm{mg} / \mathrm{l}$ & $76 \mathrm{mg} / \mathrm{l}$ \\
\hline $\begin{array}{l}\text { Magnesium } \\
\text { hardness }\end{array}$ & $80 \mathrm{mg} / \mathrm{l}$ & $16 \mathrm{mg} / \mathrm{l}$ \\
\hline $\begin{array}{c}\text { Calcium } \\
\text { concentration }\end{array}$ & $28 \mathrm{mg} / \mathrm{l}$ & $30.4 \mathrm{mg} / \mathrm{l}$ \\
\hline $\begin{array}{c}\text { Magnesium } \\
\text { concentration }\end{array}$ & $19.2 \mathrm{mg} / \mathrm{l}$ & $6.4 \mathrm{mg} / \mathrm{l}$ \\
\hline $\mathrm{Ph}$ & 10.316 & 9.347 \\
\hline Conductivity & $727.9 \mu \mathrm{S}$ & $2.224 \mu \mathrm{S}$ \\
\hline TDS & $379.7 \mathrm{ppm}$ & $108.1 \mathrm{ppm}$ \\
\hline
\end{tabular}

DIRECT SHEAR RESULTS

\begin{tabular}{|c|c|c|}
\hline Test No. & $\begin{array}{c}\text { Normal Stress } \\
\left(\mathbf{N} / \mathbf{m m}^{\mathbf{2}}\right)\end{array}$ & $\begin{array}{c}\text { Shear Stress } \\
\left(\mathbf{N} / \mathbf{m m}^{\mathbf{2}}\right)\end{array}$ \\
\hline 1 & 0.1 & $2.163 \times 10^{-2}$ \\
\hline 2 & 0.2 & $2.273 \times 10^{-2}$ \\
\hline 3 & 0.3 & $2.713 \times 10^{-2}$ \\
\hline
\end{tabular}

1.Angle of Internal friction of the given soil sample $=37^{0}$

2. Cohesion of the given soil sample $=2.163 \mathrm{~N} / \mathrm{cm}^{2}$ $=0.021 \mathrm{~N} / \mathrm{mm}^{2}$

TEST ON CHEMICAL PROPERTIES OF SOIL

\section{IDENTIFYING THE CONTAMINANTS IN THE SOIL} SAMPLE

The main soil pollutant present in the soil are heavy metals and arsenic; organic substances and organic compounds; residues of non-biodegradable pesticides, pharmaceuticals and radionuclide. The heavy metals present in the soil sample can be identified with the help of Scanning Electron Microscope (SEM) and Energy Dispersive X-Ray Analysis (EDAX).

\section{SEM ANALYSIS OF CHROMIUM CONTAMINATED SOIL}

Published By: 


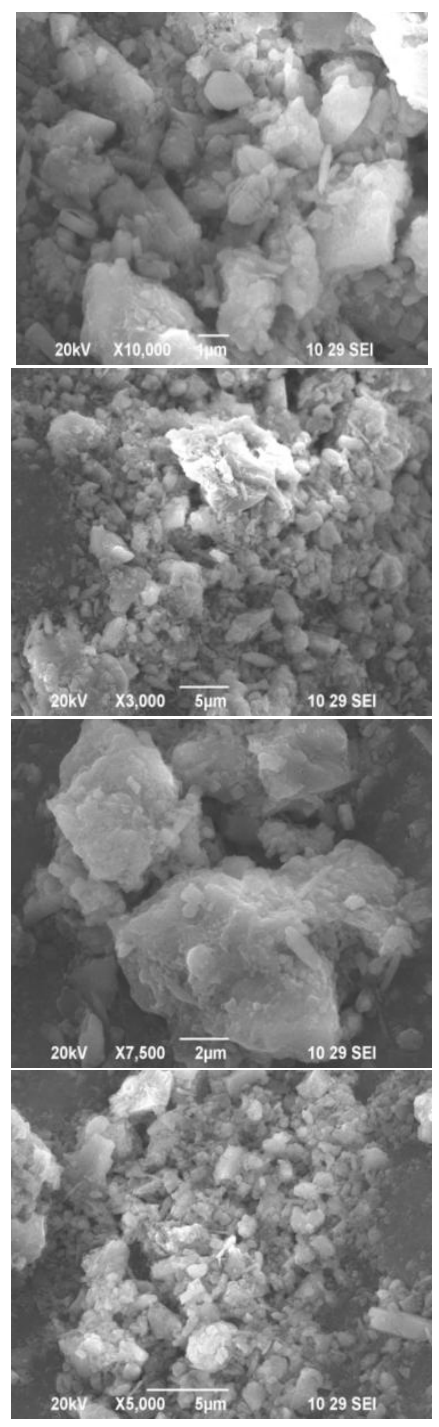

\section{EDAX ELEMENTAL ANALYSIS OF CHROMIUM CONTAMINATED SOIL}

\begin{tabular}{|c|c|c|c|c|c|}
\hline Element & $\begin{array}{c}\text { App } \\
\text { Conc. }\end{array}$ & $\begin{array}{c}\text { Intensity } \\
\text { Corrn. }\end{array}$ & $\begin{array}{c}\text { Weight } \\
\mathbf{\%}\end{array}$ & $\begin{array}{c}\text { Weight } \\
\mathbf{\%} \\
\text { Sigma }\end{array}$ & $\begin{array}{c}\text { Atomic } \\
\%\end{array}$ \\
\hline $\mathrm{O} \mathrm{K}$ & 35.27 & 0.7715 & 56.47 & 0.82 & 74.67 \\
\hline $\mathrm{Na} \mathrm{K}$ & 0.58 & 0.6231 & 1.16 & 0.22 & 1.07 \\
\hline $\mathrm{Mg} \mathrm{K}$ & 1.57 & 0.6069 & 3.19 & 0.20 & 2.77 \\
\hline $\mathrm{Al} \mathrm{K}$ & 2.12 & 0.6994 & 3.74 & 0.19 & 2.93 \\
\hline $\mathrm{Si} \mathrm{K}$ & 4.36 & 0.7744 & 6.96 & 0.23 & 5.24 \\
\hline $\mathrm{K} \mathrm{K}$ & 0.33 & 1.0888 & 0.38 & 0.11 & 0.21 \\
\hline $\mathrm{Ca} \mathrm{K}$ & 12.97 & 1.0133 & 15.82 & 0.36 & 8.35 \\
\hline $\mathrm{Cr} \mathrm{K}$ & 2.51 & 0.8362 & 3.71 & 0.21 & 1.51 \\
\hline $\mathrm{Fe} \mathrm{K}$ & 5.73 & 0.8244 & 8.58 & 0.34 & 3.25 \\
\hline
\end{tabular}

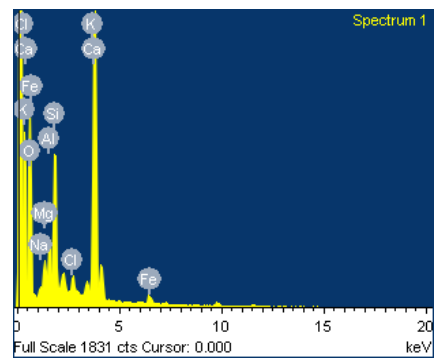

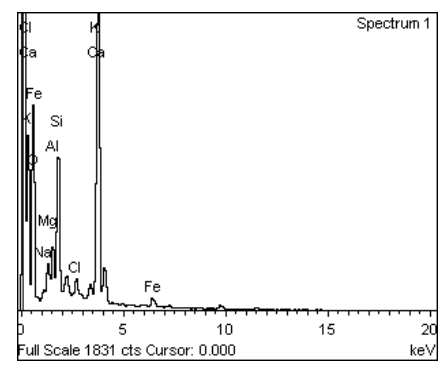

\section{MICRO ORGANISMS USED}

$>$ Pseudomonas aeruginosa

$>$ Pseudomonas alcaligenes

$>$ Pseudomonas hibiscicola

\section{REMEDIATION USING MICRO ORGANISMS}

$>$ Nutrient Agar with the addition of various concentrations of $\mathrm{K}_{2} \mathrm{Cr}_{2} \mathrm{O}_{7}$ was prepared, autoclaved with all glass wares for 45 minutes and poured in Petri dishes inside laminar air flow chamber.

$>$ The agar was allowed to solidify for 10 minutes.

$>$ After solidification the inoculums from the mother culture of the three micro organisms were streaked on the Petri dishes.

$>$ The plates were incubated for 24 hours at $37^{\circ} \mathrm{C}$.

$>$ The plates with $\mathrm{K}_{2} \mathrm{Cr}_{2} \mathrm{O}_{7}$ were checked for the growth of micro organisms.

$>$ Nutrient broth was prepared and auto claved and the grown organisms in the petri dishes were selected.

$>$ The colonies were picked and added in the nutrient broth.

$>$ The flasks containing the nutrient broth were kept in $37^{0} \mathrm{C}$ rotary shaker for 24 hours.

$>$ The broths were centrifuged and the pellets were stored in $\mathrm{NaCl}$ solution.

$>$ In a glass conical flask, $1000 \mathrm{ml}$ of distilled water was added with $1000 \mathrm{mg}$ of the contaminated soil sample.

$>$ The solution was mixed thoroughly with the help of magnetic stirrer at the rpm of 800 for 15 minutes.

$>$ The resulting solution was poured in beakers each containing $100 \mathrm{ml}$.

$>$ The beakers were inoculated with the bacterial culture stored in the $\mathrm{NaCl}$ solution.

$>$ The study was performed for 100 hours.

$>$ During the study $\mathrm{pH}$, temperature, absorbances, percentage of transmittance were recorded.

$>$ Finally, atomic absorption spectroscopy test was taken for all the samples at $0^{\text {th }}$ hour and also at $100^{\text {th }}$ hour to compare the reduction of heavy metals in the soil samples and to find the percentage reduction.

Preparation of $\mathrm{K}_{2} \mathrm{Cr}_{2} \mathrm{O}_{7}$

\begin{tabular}{|c|c|}
\hline $\mathbf{P p m}$ & Amt of $\mathbf{K}_{\mathbf{2}} \mathbf{C r}_{\mathbf{2}} \mathbf{O}_{\mathbf{7}}(\mathbf{g} / \mathbf{1 0 0 m})$ \\
\hline 25 & 0.007 \\
\hline 50 & 0.014 \\
\hline 75 & 0.021 \\
\hline 100 & 0.028 \\
\hline
\end{tabular}

Atomic Absorption Spectroscopy of 


\section{Chromium contaminated soil}

Permissible limit for Chromium is $250 \mathrm{mg} / \mathrm{l}$

$>$ The chromium concentration present in the soil sample before remediation was $285 \mathrm{mg} / \mathrm{l}$

\begin{tabular}{|c|c|c|}
\hline Ppm & $\begin{array}{c}\text { Treated at } \mathbf{1 0 0}^{\text {th }} \\
\text { hour }\end{array}$ & \% reduction \\
\hline $25(1)$ & 242 & 15.08 \\
\hline $25(2)$ & 187 & 34.38 \\
\hline $50(1)$ & 177 & 37.89 \\
\hline $50(2)$ & 195 & 31.57 \\
\hline $75(1)$ & 144 & $\mathbf{4 9 . 4 7}$ \\
\hline $75(2)$ & 148 & 48.07 \\
\hline $75(3)$ & 152 & 46.66 \\
\hline $100(1)$ & 163 & 42.80 \\
\hline
\end{tabular}

$>$ Atomic Absorption Spectroscopy of Dredged Sea Soil

$>$ Permissible limit for Iron is 0.3

$>$ The iron concentration present in the sample before remediation was $1.12 \mathrm{mg} / \mathrm{l}$

\begin{tabular}{|c|c|c|}
\hline ppm & $\begin{array}{c}\text { Treated at 100 } \\
\text { hour }\end{array}$ & \% reduction \\
\hline $25(1)$ & 0.6 & 46.42 \\
\hline $25(2)$ & 0.7 & 37.5 \\
\hline $50(1)$ & 0.8 & 28.57 \\
\hline $50(2)$ & 0.7 & 37.5 \\
\hline $75(1)$ & 0.9 & 19.64 \\
\hline $75(2)$ & 1 & 10.71 \\
\hline $75(3)$ & 0.8 & 28.57 \\
\hline $100(1)$ & 0.9 & 19.64 \\
\hline
\end{tabular}

\section{CONCLUSION}

The soil samples were collected and then the soil properties were studied. Various soil tests such as sieve analysis test, plastic limit test, liquid limit test and specific gravity test were done to understand the engineering characteristics of the soil. Chemical tests such as $\mathrm{pH}$ test, conductivity test, total dissolved solids test, chloride tests and hardness test were also done to understand the chemical properties of the soil. The in-depth analysis of soil structures was understood with the help of Scanning Electron Microscope (SEM) and the concentration of chemical elements present in the soil sample were determined with the help of Energy Dispersive X-Ray Analysis (EDAX). From the tests carried out on the contaminated soil samples before and after treatment using micro organisms it is concluded that for chromium contaminated soil the bacteria named Pseudomonas alcaligenes when added with 75 ppm of potassium dichromate contributes to nearly $49.47 \%$ reduction in the chromium concentration of the soil sample and for harbor dredged sea soil the bacteria named Pseudomonas aeruginosa when added with $25 \mathrm{ppm}$ of potassium dichromate contributes to nearly $46.42 \%$ reduction in iron concentration present in the soil sample.

\section{REFERENCE}

1. W. Kamolpornwijit, J. N. Meegoda, J. H. Batagoda (2015) "Engineering Properties of Chromium Contaminated Soils" New Jersey Institute of Technology, Newark.

2. Pallabi Borah, Pooja Singh, LathaRangan, TanmoyKarak, SudipMitra (2018) "Mobility, bioavailability, and ecological risk assessment of cadmium and chromium in soil contaminated by paper mill wastes" Department of Environmental science, Tezpur University, Napaam, Sonitpur, Assam - 784028.

3. N.Calace, T.Campisi, A.Lacondini, M.Leoni (2005) "Metal contaminated soil remediation by means of paper mill sludge's addition: chemical and ecotoxological evaluation" Department of Chemistry, University of Rome, Italy.

4. P. Cauwenberg, F. Verdonckt, A. Maes (1998) "Flotation as a remediation technique for heavily polluted dredged material" Katholique University Leuven, Laboratory of Colloid Chemistry, KardinaalMercierlaan 92, 3001 Heverlee, Belgium.

5. N. Christofi, I.B. Ivshina (2002) "Microbial surfactants and their use in field studies of soil remediation" Pollution Research Unit, School of Life Sciences, Napier University, Edinburgh, Scotland, UK.

6. WANG Ying, FENG Jiang, LIN Qianxin, LYU Xianguo, WANG Xiaoyu (2013), WANG GuopingEffects of Crude Oil Contamination on Soil Physical and Chemical

7. Properties in Momoge Wetland of China

8. Pablo M. Fernandez, Silvana C. Vinarta , Anahí R. Bernal , Elias L. Cruz ,Lucia I.C. Figueroa (2013) "Bioremediation strategies for chromium removal: Current research,

9. scale-up approach and future perspectives" PlantaPiloto de ProcesosIndustrialesMicrobiologicos PROIMICONICET, Av. Belgrano y Caseros, T4001MVB San Miguel de Tucum an, Tucum an, Argentina.

10. Ji Dong GU (2018) "Mining, pollution and site remediation" College of Environmental Sciences, University of China, Wuham, PR China.

11. Sana Khalid, Muhammad Shahid, Nabeel Khan Niazi, BehzadMurtaza, IrshadBibi, Camille Dumat (2016) “ A comparison of technologies for remediation of heavy metal contaminated soils" Department of Environmental Sciences, COMSATS Institute of Information Technology, Vehari-61100, Pakistan.

12. Jong-Oh Kim, Jeongyun Choi, Seongeon Lee, Jinwook Chung (2016) "Evaluation of hydro cyclone and posttreatment technologies for remediation of contaminated dredged sediments" Department of Civil and Environmental Engineering, Hanyang University, 222 Wangsimni-Ro, Seongdong-Gu, Seoul 133-791, Republic of Korea.

13. Mee Wei Lim, Ee Von Lau, PhaikEongPoh (2016) “A comprehensive guide of remediation technologies for oil contaminated soil-Present works and future directions" School of Engineering, Monash University Malaysia, Jalan Lagoon Selatan, 47500 Bandar Sunway, Selangor DarulEhsan, Malaysia.

14. Ping Lu, QiyanFeng, QingjunMeng, Tao Yuan (2012) "Electro kinetic remediation of chromium- and cadmium-contaminated soil from abandoned industrial site" School of Environmental Science and Spatial Informatics, China University of Mining and Technology, Xuzhou 221116, Jiangsu, China. 
15. Todd.A.Martin, Michael V.Ruby (2004) “ Review of insitu remediation technologies for Lead, Zinc and Cadmium in Soil"

16. P. Mattei , A. Cincinelli, T.Martellini, R. Natalini, E. Pascale , G. Renella (2016) "Reclamation of river dredged sediments polluted by PAHs by co-composting with green waste" Department of Agrifood Production and Environmental Sciences, University of Florence, Florence, Italy.

17. Catherine N. Mulligan, Raymond N. Yong, Bernard F. Gibbs (2001) "An evaluation of technologies for the heavy metal remediation of dredged sediments" Department of Building, Civil and Environmental Engineering, Concordia University, Canada.

18. "Electrodialytic Remediation of Soil Polluted with Copper from Wood Preservation Industry" Department of Chemistry and Department of Geology and Geotechnical Engineering, Technical University of Denmark, 2800 Lyngby, Denmark.

19. Muhammad Zia urRehmana, Muhammad Rizwanb, ShafaqatAlib, Yong SikOkc, WajidIshaqued, Saifullahe, Muhammad FarrakhNawazf, Fatima Akmala, MaqsoodaWaqar (2017) "Remediation of heavy metal contaminated soils by using Solanumnigrum: A review" Institute of Soil and Environmental Sciences, University of Agriculture, Faisalabad 38040, Pakistan.

20. Isam Al Zubaidi, Adil Al Tamimi (2018) “ Soil remediation from waste lubricating oil" Faculty of Engineering and Applied Science, University of Regina, Canada.

21. QianruiWanga, DaekeunKima, Dionysios D. Dionysioua,George A. Soriala,, Dennis Timberlake (2004) "Sources and remediation for mercury contamination in aquatic systems- literature review" Department of Civil. 